\title{
Unstash the Cash! Corporate Governance Reform in Japan
}

\author{
Chie Aoyagi ${ }^{1}$ \\ International Monetary Fund, Regional Office for Asia and the Pacific, Japan \\ CAoyagi@imf.org \\ Giovanni Ganelli \\ International Monetary Fund, Regional Office for Asia and the Pacific, Japan \\ GGanelli@imf.org
}

\begin{abstract}
Japan's high corporate savings might be holding back growth, by preventing a more efficient use of resources. Small and medium enterprises (SMEs) have been the main contributors to high corporate cash balances, but more recently larger companies have also increased cash holdings. This paper focuses on the causes and consequences of the current corporate behavior and suggests options for reform. In particular, Japan's weak corporate governance - as measured by available indexes - might be contributing to high cash holdings. An empirical analysis on a panel of Japanese firms confirms that improving corporate governance would help unlock corporate savings. The main policy implication of the analysis carried out in this paper is that a more ambitious and comprehensive corporate governance reform should be a key component of Japan's growth strategy. Such a reform would help remove some of the bottlenecks of the legal and corporate governance framework which encourage high corporate cash holdings and prevent a more pro-growth use of resources.
\end{abstract}

JEL Classification Numbers: D22; G30; G34

Keywords: Japan; corporate cash holdings; corporate governance; growth strategy.

\section{INTRODUCTION}

The contribution of this paper is twofold. First, it contributes to the empirical literature on the determinants of corporate cash holdings. In particular, using a panel of Japanese corporations, the paper shows that improving corporate governance can significantly reduce corporate cash holdings. Second, the paper contributes to the policy debate on the strategy to revive growth

Corresponding author: 21F, Fukoku Seimei Bldg., 2-2-2 Uchisaiwai-cho, Chiyoda-ku, Tokyo 100-0011, Japan, Tel:+81-3-3597-6700, Fax:+81-3-3597-6705.

The views expressed in this paper are those of the author(s) and do not necessarily represent the views of the IMF, its Executive Board, or IMF management. 
and decisively exit from deflation in Japan, by drawing policy implications from the analysis and suggesting some reforms which could facilitate a more efficient use of corporate resources.

Japan's corporate sector stands out in terms of its high cash holdings compared to other advanced countries. While high firms' cash holdings play some positive roles, such as providing insurance against shocks, they also imply high macroeconomic costs if they prevent resources from being used in a more efficient way. This is likely to be relevant in Japan, where high cash holdings coexist with a negative contribution of private investment to growth in the last few years and with falling real wages in the face of positive labor productivity growth for most of the last two decades. In this context, Japan's high cash holdings are likely to be holding back both potential and short-term growth.

Given that holding large amounts of cash on their balance sheets - rather than investing or paying higher wages - might be rational for individual firms if they expect other firms to do the same, there seems to be space for policies to break this sub-optimal equilibrium and encourage more risk taking in the corporate sector. Accordingly, this paper focuses on the causes and economic consequences of the current corporate behavior and suggests options for reform.

Our main interest in this paper is to test the hypothesis that:

- There is a positive relationship between improved corporate governance and reduced cash holdings in Japan.

Various determinants of cash holdings have been highlighted in the previous literature. Keynes (1934) refers to the "transaction cost" and the "precautionary" motives for holding cash. The former means that, by holding cash, firms can save transaction costs to raise funds, while the latter refers to the fact that the firms can use cash to finance their activities if other sources of funding are not available. Other papers have focused on the trade-off between costs and benefits of holding cash. The costs considered in this literature include brokerage costs (Miller and Orr 1966) and inefficient investment resulting from insufficient liquidity (Jensen and Meckling 1976; Fazzari et al. 1988). Opler et al. (1999) find empirical support for the trade-off theory. Under this theory, firms tend to hold more cash when they are smaller, when they have more volatile cash flows, and invest more.

An alternative theory considered by Myers and Majluf (1984) and Opler et al. (1999) is the financing hierarchy theory, under which there is no optimal amount of cash and cash balances are simply the outcome of firms' profitability and financing needs. While some predictions of the two theories are similar, an important difference is that under the financing-hierarchy theory firms which invest more will have less cash.

In addition to the determinants highlighted in the previous literature on corporate cash holdings, discussed above, several Japan-specific factors - including entrenched deflation expectations; aversion to bankruptcies and lack of pre-packaged bankruptcy procedures; takeover regulations and ownership structure; role of banks in financing firms; and weak corporate governance - might be encouraging Japanese firms to hold excessive cash on their balance sheets. In particular, a cross-country comparison of corporate governance indexes shows that Japan scores lower than other G-7 countries regarding firm-level governance attributes, covering: board composition; audit quality; shareholder rights; and ownership structure and compensation.

Previous studies have shown that good corporate governance is a significant factor in reducing cash holdings. La Porta et al. (2000), for example, find that good shareholder protection in the U.S. imply that shareholders can force managers to return excess funds to them. Similarly, Dittmar et al. (2003) show that corporate cash holdings in countries in which shareholder rights are not well protected are twice as much as those in countries with good shareholder protection. This literature suggests that improving corporate governance could go a long way toward unlocking Japan's corporate savings. 
The hypothesis of a relationship between improved corporate governance and reduced cash holdings in Japan is confirmed by the empirical analysis carried out on this paper on a panel of about 3,400 Japanese firms. The results suggest that improving corporate governance in Japan - proxied in the regression by an index summarizing company disclosure of governance data - could significantly reduce corporate cash holdings. In addition, corporate governance reform could have significant second round effects. By encouraging higher investment and nominal wages, such reforms would help Japan exit from deflation, which in turn would make holding cash on firms' balance sheets more costly, thus encouraging further corporate spending in a selfreinforcing virtuous circle.

The policy implications of the research presented in this paper are clear: comprehensive corporate governance reform should be an important component of the government's growth strategy. In this regard, recent steps taken by the authorities go in the right direction, including the introduction of the Stewardship Code for institutional investors and encouraging the use of independent outside directors on a "comply or explain" basis. However, in light of the encouraging empirical results presented here, reforms could be more ambitious. In this context, the paper proposes and discusses some possible additional measures, including expanding the use of independent outside directors beyond current plans.

The structure of the paper is as follows. Section II presents some stylized facts regarding Japan's high corporate cash holdings in an international perspective. Section III discusses the determinants of cash holdings, with special attention to Japan-specific factors. Section IV looks in detail at Japan's corporate governance indicators from an international perspective. Section V states our hypothesis. Section VI presents some empirical evidence based on a panel of Japanese firms, which confirms that improving corporate governance could reduce corporate cash holdings in Japan. Section VII discusses progress made in corporate governance reform in Japan so far and provides some policy recommendations. Section VIII concludes.

\section{CORPORATE JAPAN'S HIGH CASH HOLDINGS}

Cash holdings by Japanese companies are very high compared to other G-7 countries. As it can be seen in the text chart, the average ratio of cash and cash-equivalent holdings to market capitalization of Japanese listed companies during 2004-2012 was above 40 percent in Japan, compared to values in the 15-27 percent range in other G-7 countries.

Listed companies' cash and cash equivalents holdings (\% of market capitalization; Average between 2004 and 2012)

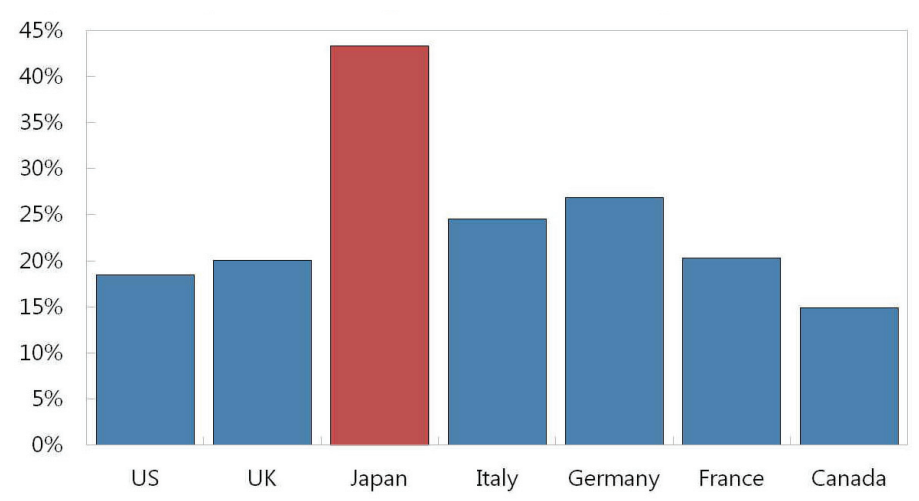

Sources: Bloomberg. 
Japan's high cash holdings are not driven by a particular industrial sector but rather broadbased. In theory, some sectors might face greater need to hold cash than others. However, in Japan, currently most sectors' cash balances as percentage of their market capitalizations are higher than the G-7 average (excluding Japan and Italy) of 24 percent in 2012 and of 19 percent between 2000 and 2012, suggesting that Japan's high cash balance phenomenon is not particularly driven by industry-specific factors (see text chart).

Firms’ cash holdings by sector 2013 (\%; Cash and cash equivalent/Market Capitalization)

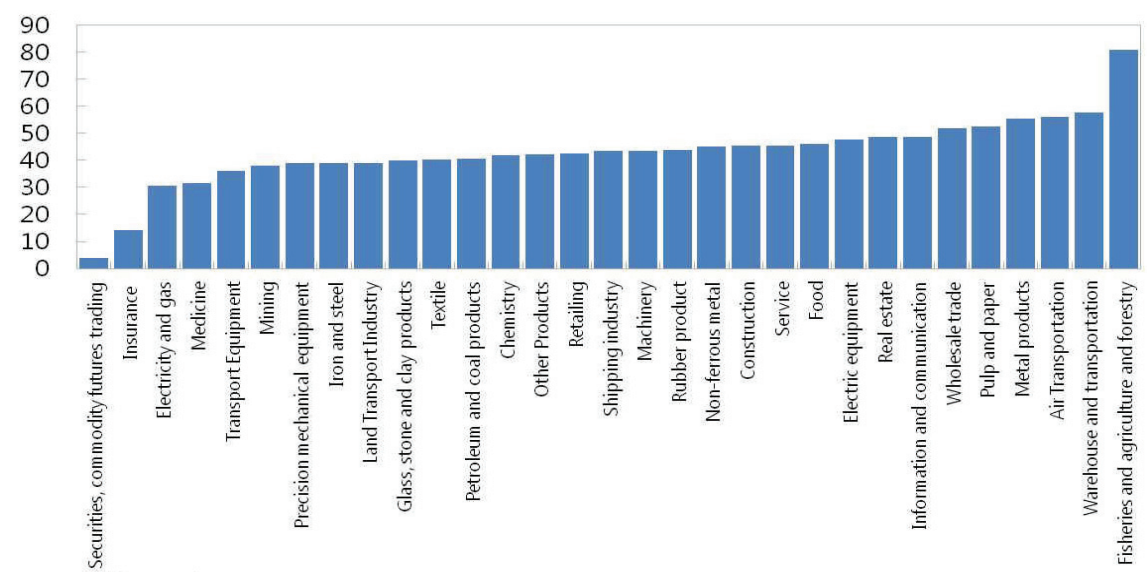

Sources: Bloomberg.

Small and medium enterprises (SMEs) have been the main contributors to high corporate cash balances, but more recently larger companies have also increased cash holdings. A Ministry of Finance survey shows that SMEs have held over 15 percent of total assets as cash and deposits for most years since 1960, and more recently the share has been increasing to around 20 percent. SMEs' high cash holdings were coincident with high debt. Despite the trend of deleveraging across firms after the bubble burst in 1990s, SMEs rely more on borrowing from financial institutions than larger firms, while continuing to hoard cash. Furthermore, the post 2008 crisis trend suggests that larger companies, which had reduced cash holdings from their peak in the late 1980s, have also re-started accumulating cash (text chart).

Cash and Deposit Holdings by Firm Size (\% of total assets; Non-financial companies)

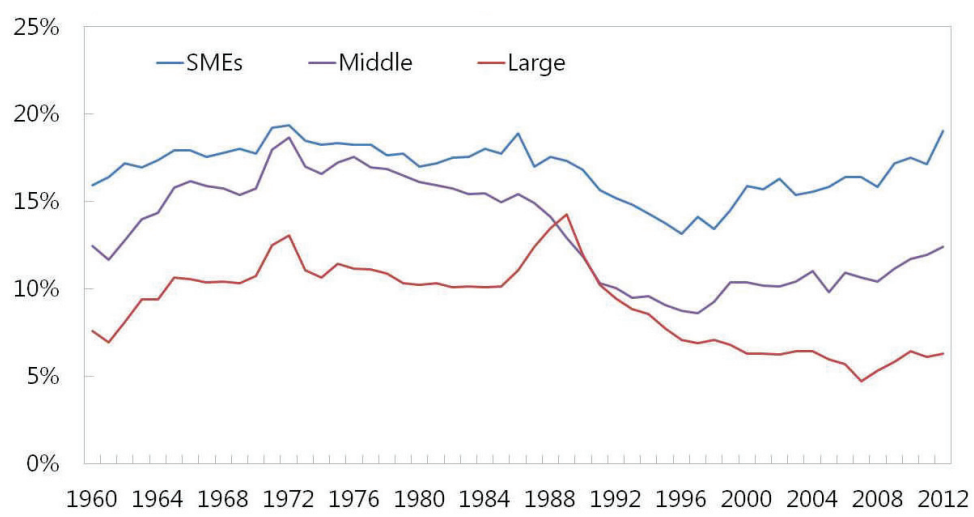

Sources: Ministry of Finance of Japan.

The data discussed above suggest that Japan's corporate cash holdings might be excessive and not justified by economic fundamentals. This is consistent with the results of Ivanova and Raei (2014) who find that Japanese firms have exhibited an excessive increase in cash holdings in 
recent years compared to what a standard model of corporate demand for cash would imply. Such excessive corporate savings are likely to be detrimental for the economy. Japan's corporations' preferences for holding a large amount of cash might be preventing them from increasing wages and investment, thus holding back both aggregate demand and potential growth. This view is consistent with the results of Shinada (2012), who uses Japanese firm-level data for 1980-2010 to analyze the impact of cash holdings on business performance. His results suggests that firms' conservative cash management regardless of large investment opportunities increases "sideline" cash, and firms cannot fully utilize investment opportunities to maximize their return on assets. Given the macro-relevance of excessive corporate cash holdings, this paper looks at their determinants and provides some policy recommendations to reduce them.

\section{DETERMINANTS OF CASH HOLDINGS}

The literature has highlighted various determinants of firms' cash holdings, but there is no overwhelming support for a unified theory. In the early literature, transaction costs were considered as the main determinants of cash levels, and firms with higher marginal costs of cash shortfalls were expected to have higher cash holdings (Miller and Orr 1966; Meltzer 1993; Mulligan 1997). Opler et al. (1999) find empirical support for the trade-off theory, which suggests that firms consider not only the costs but also the benefits of holding cash to derive optimal cash levels. Under this theory, firms tend to hold more cash when they are smaller, when they have more volatile cash flows, and invest more. In addition, the trade-off theory incorporates the effect of agency problems between shareholders and managers, as they tend to view the costs and benefits of cash holdings differently. An alternative theory considered by Opler et al. (1999), for which they also find some support in their analysis, is the financing-hierarchy theory, under which there is no optimal amount of cash and cash balances are simply the outcome of firm profitability and financing needs. While some predictions of the two theories are similar, an important difference is that under the financing-hierarchy theory firms which invest more will have less cash.

Some recent studies on corporate cash holdings highlight the importance of legal protection of investors. Kusnadi and Wei (2011) argue that firms in countries with strong legal protection of minority investors are more likely to decrease their cash holdings compared to firms in countries with weak legal protection. Yung and Nafar (2014) find that the tendency to hold excessive cash motivated by high creditor rights is mitigated in countries with strong investor protection.

Previous cross-country studies have shown that good corporate governance tends to reduce corporate cash holdings. Corporate cash holdings have both costs and benefits, but these differ from the managers' and shareholders' points of view, thus creating an agency problem. Holding cash provides insurance against macroeconomic shocks, which is a benefit from the point of view of both the managers and the shareholders. However, in the absence of strong corporate governance, managers might have a preference for much higher levels of cash holdings compared to those which would maximize shareholders' value. A cross-country analysis carried out by Dittmar et al. (2003) conclude that corporate governance is an important determinant of cash holdings, since their results show that corporate cash holdings in countries in which shareholder rights are not well protected are twice as much as those in countries with good shareholder protection.

In the context of Japan, the economic environment as well as some characteristics of the legal and corporate-governance framework might contribute to large corporate savings, both by increasing managers' preferences for cash holdings and by exacerbating the agency problem. These are discussed in more detail below.

Starting with the economic environment, entrenched deflationary expectations are likely to be an important determinant of large cash holdings in Japan. A deflationary environment lowers 
the opportunity cost of holding cash for both managers and shareholders. As stressed by Bank of Japan (BoJ) Governor Kuroda in a recent speech, deflation encourages holding cash over alternative more productive uses of resources. ${ }^{2}$ Even though recent developments suggest that Japan has made progress towards reviving growth and exiting deflation, if firms do not believe that the recovery is long-lasting and that there are profitable investment opportunities, they can be reluctant to reduce their cash holdings.

Moving to factors related to the legal framework, bankruptcy procedures might increase managers' preference for precautionary cash holdings in Japan. Japanese firms might tend to accumulate larger cash balances as a form of insurance against having to file for bankruptcy. Kinoshita (2013) makes the point that, due to the lack of pre-packaged bankruptcy reorganization procedures, the threats faced by managers when filing for bankruptcy in Japan are higher than those faced in the other advanced countries, such as the US and Germany. For example, in Japan management faces a higher threat of loss of initiative in the enterprise and of being prosecuted under civil and criminal law in case of bankruptcy.

As shown in Table 1, which compares Japan to the US and Germany, only a small number of bankruptcy applications are made in Japan for reorganization (as few as 420 in 2012). Even after taking into account differences in the size of the Japanese and US economies, this is in stark contrast with the much higher number of applications made under Chapter 11 in the US. In comparing Japan with Germany, the fact that the German procedure of Insolvenzordnung does not distinguish between reorganization and liquidation needs to be taken into account. Even assuming that half of the Insolvenzordnung procedures will end up in liquidation and half in reorganization, Japan again stands out as having a very low number of reorganization procedures. The fact that reorganization procedures are not widespread in Japan implies that managers might want to hoard cash as a way to avoid having to file for bankruptcy.

Kinoshita (2013) also makes the point that the filing of a bankruptcy substantially increases the threat of dismissal for employees in Japan compared to the US. Japanese employees are therefore likely to be more adverse to bankruptcies compared to US employees, which can also contribute to higher precautionary cash holdings of firms.

Table 1.

Bankruptcy Procedures in Selected Countries

\begin{tabular}{lcccccccccc}
\hline \hline & 2003 & 2004 & 2005 & 2006 & 2007 & 2008 & 2009 & 2010 & 2011 & 2012 \\
\hline United States (Chapter 11) & 9,762 & 10,882 & 6,250 & 5,701 & 4,688 & 6,274 & 10,348 & 13,583 & 11,093 & 9,616 \\
Germany (Insolvenzordnung) & 23,061 & 23,898 & 23,247 & 23,291 & 20,491 & 21,359 & 24,301 & 23,482 & 23,586 & n.a. \\
Japan (Reorganization) & 856 & 551 & 592 & 536 & 601 & 906 & 716 & 529 & 519 & 420 \\
\hline \hline
\end{tabular}

Source: Kinoshita (2014).

In Japan, takeover regulations and share ownership structure might also not provide enough pressure on managers to act in the shareholders' interests. For example, Kinoshita (2013) argues that there is a significant imbalance in the discretionary powers of the bidder and of the directors of the target enterprise in the Japanese legal system, a situation which might provide disincentives for takeovers. As a consequence, takeovers in Japan are relatively rare, thus reducing pressure on companies to use resources in a productive way.

\footnotetext{
"In a state of deflation, the holding of cash or deposits will become a relatively better investment. In fact, cash and deposits held by Japanese firms have reached 230 trillion yen, close to 50 percent of nominal GDP. Persistent deflation has created an environment in which the status quo is better than making investment in new initiatives, and has brought a sense of stagnation to Japan.", in "Overcoming Deflation: The Bank of Japan's Challenge" available at http://www.boj.or.jp/en/announcements/press/koen_2013/ko131010a.htm/
} 
Kinoshita (2013) also argues that cross-shareholding might be another contributing factor to high cash holdings, because corporations who hold stocks of other corporations might have a greater interest in so-called 'individual benefits' - such as securing credit, developing a deeper business relationship with the issuer, and pursuing the self-defense of the management bodies of both enterprises - than in the maximization of stock values. As it can be seen in the text chart, cross-shareholding in Japan is still widespread and above the European average. Against this background, many corporations in Japan, in exercising their shareholder rights, may not place adequate pressure on managers of firms whose stock they own to pursue higher monetary returns.

Share Holding Ratio by Investor Category (\%; on a value basis)

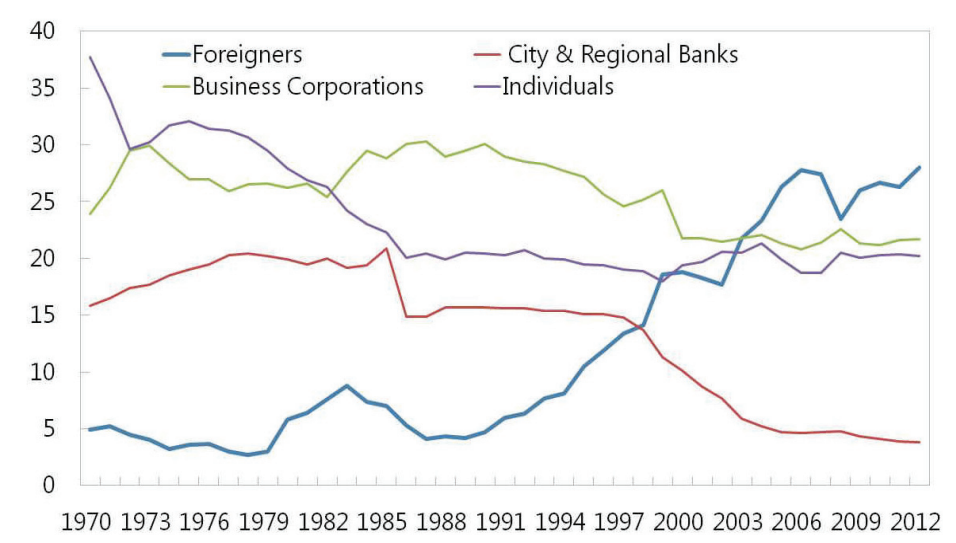

Sources: Tokyo Stock Exchange.

Share Holding Ratio by Non-financial Companies 2012

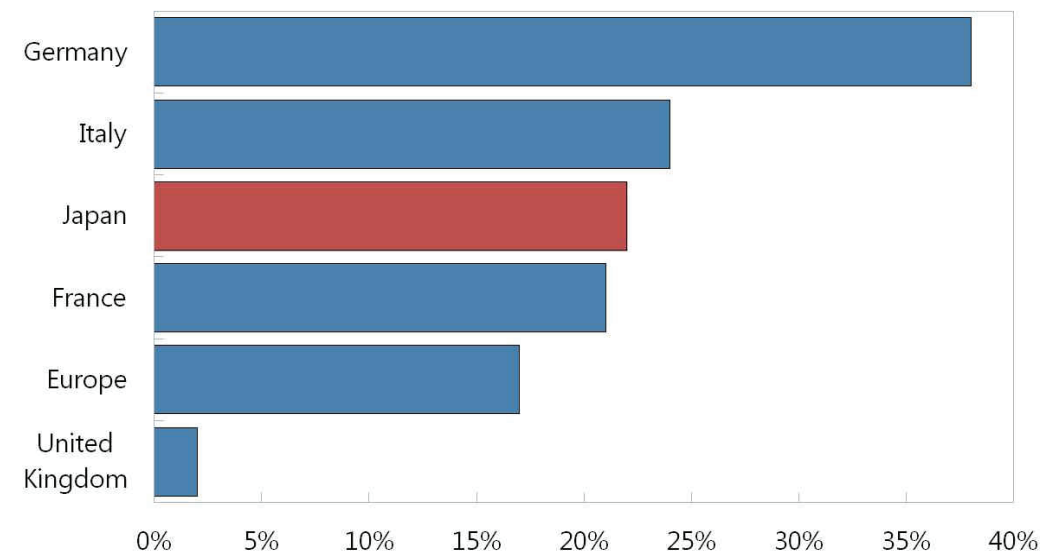

Sources: The Financial Services User Group.

The role of banks in financing firms' activities can also affect corporate cash holdings in Japan. Pinkowitz and Williamson (2001) have argued that Japanese corporate cash balances are affected by the monopolistic power of banks. Their analysis suggests that banks have an interest in extracting rents from the corporate sector by pushing companies to hoard cash rather than using it to pay down their debt. Pinkowitz and Williamson (2001) argued that this effect is important in Japan but became less strong over time as banks' monopolistic power decreased starting from the late $1980 \mathrm{~s}$, due to regulatory changes and financial sector shocks. However, as shown in the text chart, Japan's debt-to-equity ratio, which can be interpreted as a broad measure of bank's power, is still higher than in most G-7 countries. 
Dept to Equity and Cash Holding Ratio 2012 (\%; Listed Non-financial Firms)

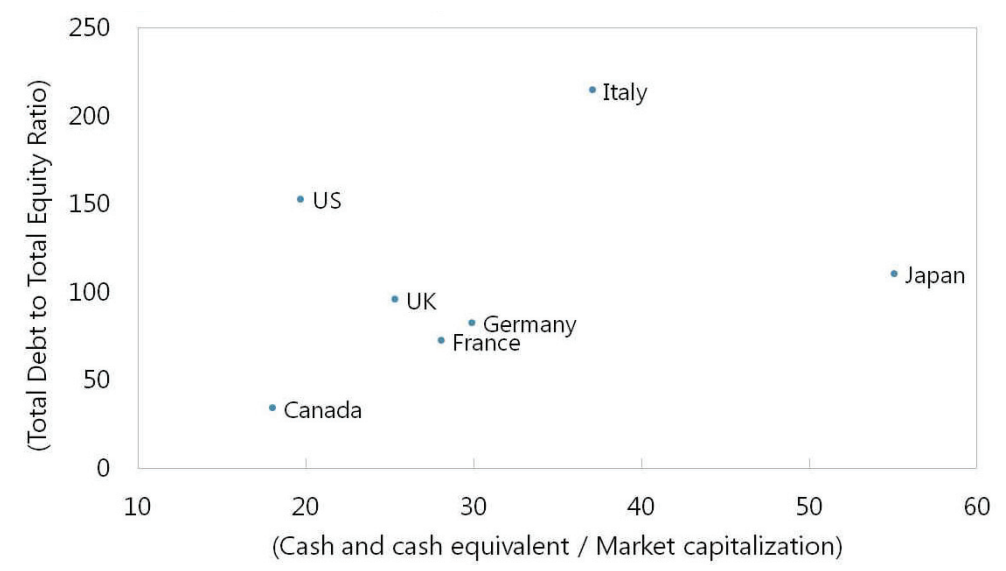

Sources: Bloomberg.

Weaker corporate governance in Japan compared to other advanced countries can also make solving the agency problem more difficult. As discussed in more detail in the next section, some internationally comparable indicators suggest that corporate governance might be weaker in Japan compared to other advanced countries. As a consequence, managers in Japan might have more leeway to pursue individual benefits rather than maximize shareholders value, thus choosing to hold more cash. Nakajima (2013) argues that weak market monitoring mechanisms and weak corporate governance make it difficult to solve the agency problem in Japan, which results in high cash holdings.

The above discussion suggests that corporate governance and legal framework reforms can be important in Japan to encourage companies to reduce cash holdings. The next section looks more in detail at Japan's corporate governance indicators from an international perspective.

\section{CORPORATE GOVERNANCE IN JAPAN: AN INTERNATIONAL COMPARISON}

An international comparison based on the Corporate Governance Quality (CGQ) index developed by De Nicolò, Laven and Ueda (2006) suggests that Japan scores low compared to other G-7 countries. The CGQ index is constructed at the country level using accounting and market data of samples of listed non-financial firms. The index is a simple average of three proxy measures of outcomes of corporate governance in the dimensions of accounting disclosure and transparency. As such, it gives an account of the de facto, as opposed to de jure, corporate governance environment in a given country. As shown in the text chart, the CGQ dynamics suggests that although Japan's corporate governance quality has improved since the early1990s, it is still the second lowest in the G7 after Italy. 
Corporate Governance Quality Index (An increase of this indicator signals an improvement in transparency)

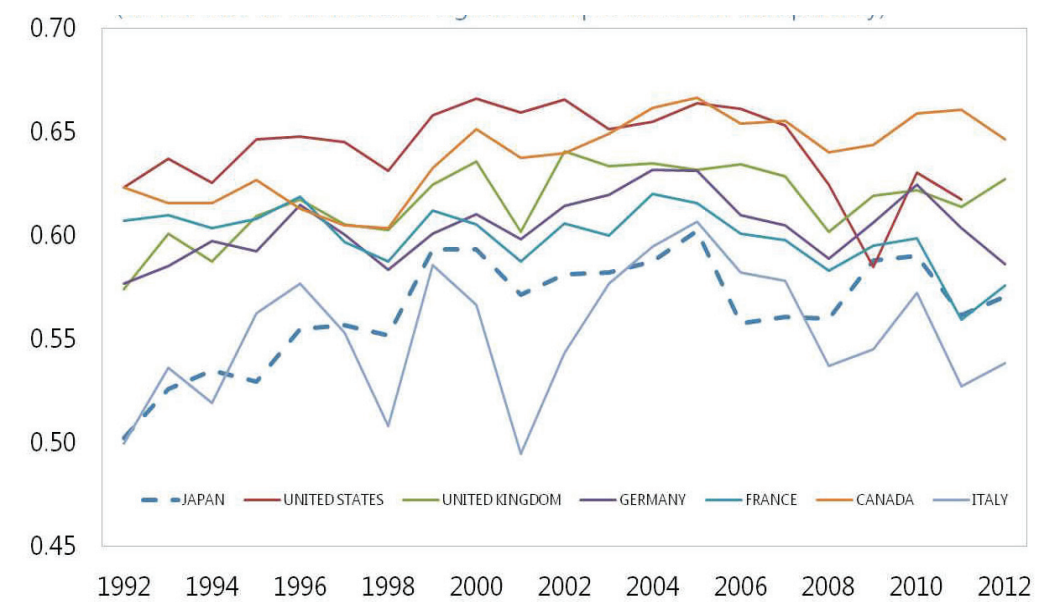

Sources: IMF, Corporate Vulnerability Utility.

A disaggregated analysis of the various components of the CGQ index suggests that Japan is doing relatively well in terms of accounting standards but less so along other important transparency dimensions. As shown in the text charts, Japan's level in the CGQ is higher than the OECD average (although still lower than most G-7 countries). Looking at the sub-components of the CGQ index, Japan is above the OECD average for the sub-indexes on "accounting standards" - a simple measure of the amount of accounting information disclosed by firms - and for the one on "stock-price synchronicity" - which aims to capture the extent to which a poor governance environment leads to investors' inability to distinguish good performers from bad performers, and of poor governance associated with inefficient connected lending. However, Japan scores quite low and considerably below the OECD average for the CGQ sub-index on "earnings smoothing" which tracks the extent to which published accounts might conceal the true performance of firms.

Corporate Governance Quality Index 2011 (An increase of this indicator signals an improvement in transparency)

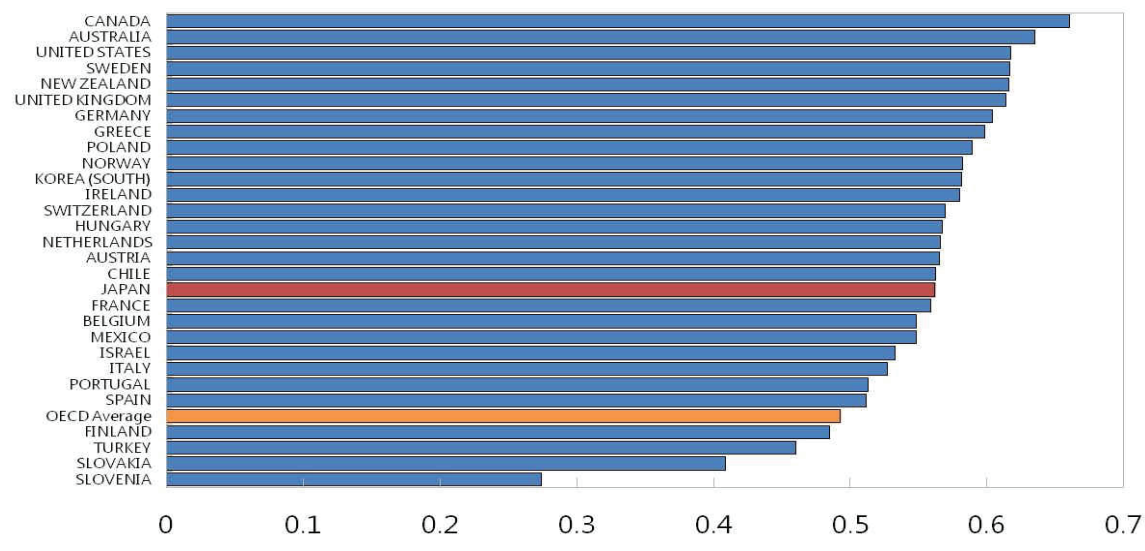

Sources: IMF, Corporate Vulnerability Utility. 
Subindex: Accounting Standards Indicator 2011 (An increase of this indicator signals an improvement in transparency)

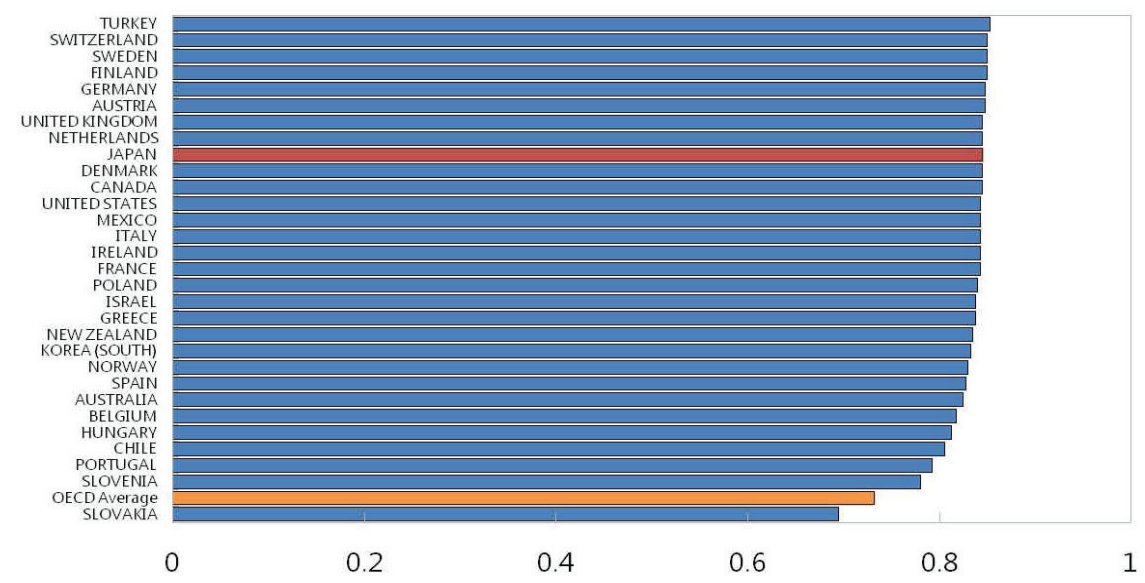

Sources: IMF, Corporate Vulnerability Utility.

Subindex: Earnings Smoothing Indicator 2011 (An increase of this indicator signals an improvement in transparency)

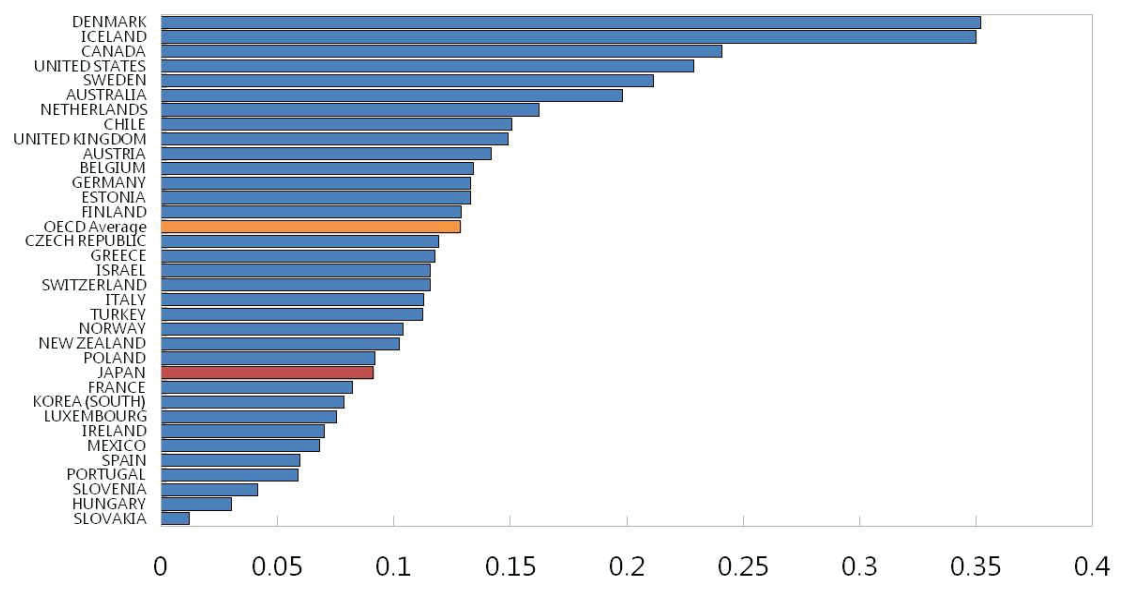

Sources: IMF, Corporate Vulnerability Utility.

Subindex: Stock Price Synchronicity Indicator 2011 (An increase of this indicator signals an improvement in transparency)

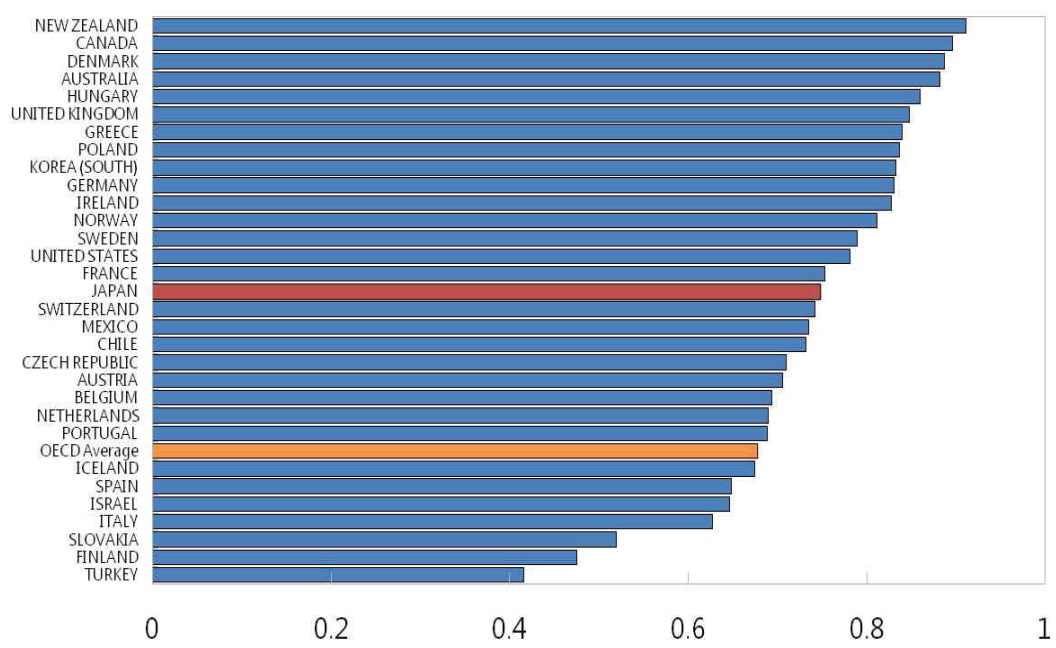

Sources: IMF, Corporate Vulnerability Utility. 
A different indicator which summarizes several de jure corporate governance firm-level attributes suggests that Japan does not fare well in an international comparison. The Firm Level Governance (FLG) index developed by Aggarwal et al.(2010) summarizes 41 firm-level governance attributes which cover four broad sub-categories: i) Board, including independence of directors and how the Board conducts its work; ii) Audit, focusing on independence and the role of auditors; iii) Anti-Take-Over Provisions, which includes some aspects of shareholder rights; and iv) Compensation and Ownership, which deals with setting and monitoring of executive and directors' compensation and stock ownership. When corporate governance is measured using the FLG, it can be seen that Japan scored consistently lower than any other G-7 country over the years. Even compared to a wider sample of advanced countries, Japan's corporate governance performance is low both in terms of level and progress made in recent years (text charts).

Firm-Level Governance Index (An increase of this index signals an improvement in corporate governance)
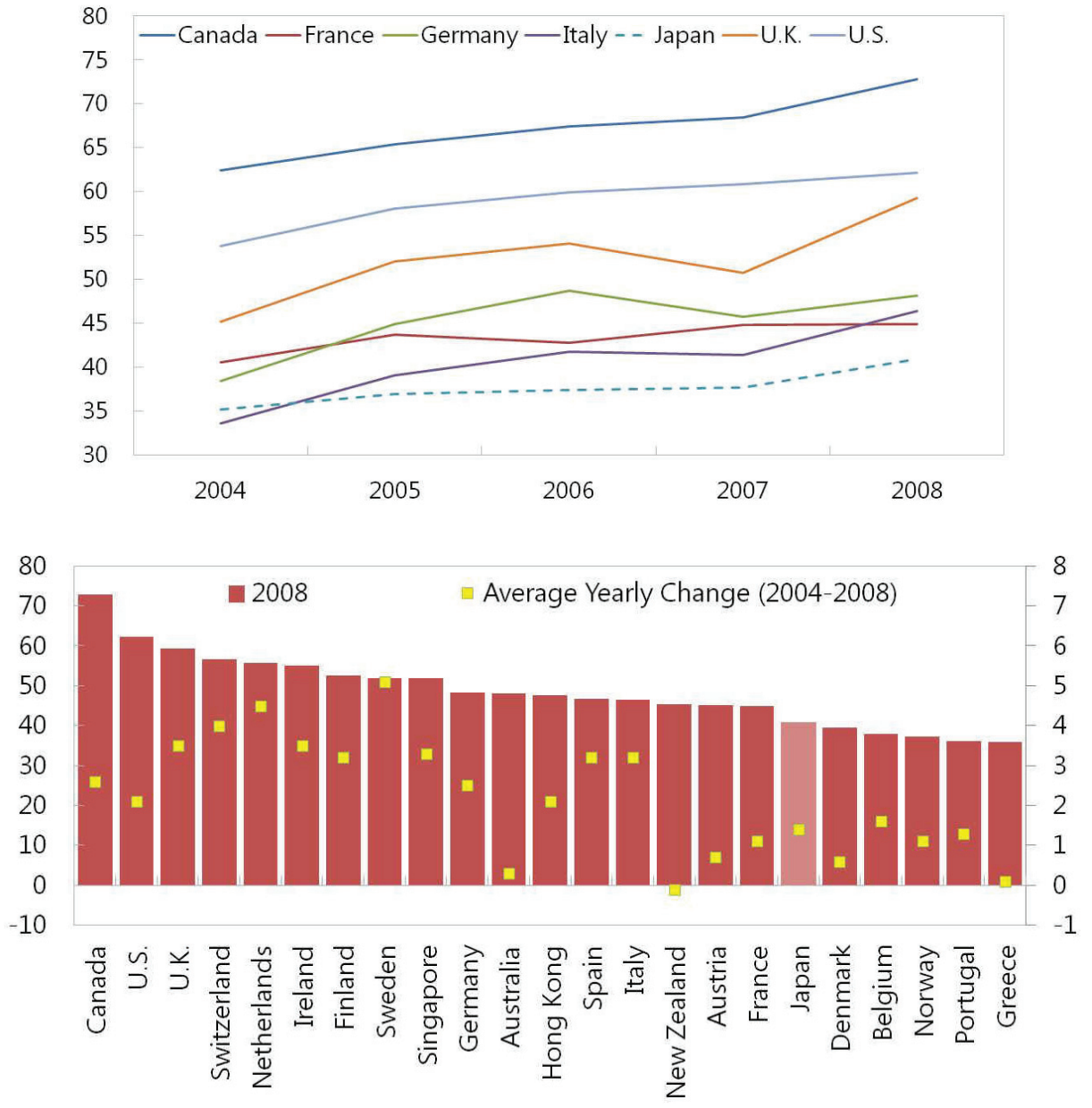

Sources: Aggarwal et al. (2010).

The discussion in Section III and the evidence presented in this section suggest that there is scope to improve corporate governance in Japan, and that corporate governance reforms can encourage a more productive use of resources by firms. As suggested by Kinoshita (2013), corporate governance regulations and practices are likely to contribute to excessive corporate cash holdings in Japan. Furthermore, an international comparison based on the CGQ and FLG indexes suggests that there is scope to improve Japan's corporate governance standards and bring it closer to that of other advanced countries. The next Section focuses more in detail on what could be the impact of improving corporate governance in Japan by presenting some regression results for a panel of Japanese companies. 


\section{HYPOTHESIS DEVELOPMENT}

Given the literature and the empirical evidence discussed above, we developed the hypothesis that improving corporate governance in Japan would, by increasing shareholder power and putting more pressure on firms' managers to use resources efficiently, reduce excessive corporate cash holdings.

The rest of the paper is devoted to empirically testing this hypothesis (i.e. testing a relationship between improved corporate governance and reduced corporate cash holdings) in Japan.

\section{CORPORATE GOVERNANCE AND CASH HOLDINGS IN JAPAN: EMPIRICAL ANALYSIS}

In this section the impact of corporate governance on corporate cash holdings is assessed by estimating a model for a panel of Japanese firms which include a firm-specific governance index. The data set includes 3,412 non-financial firms for the 14 years between 2000 and 2013 (or less, depending on data availability). The sample consists of all listed companies in Japan, excluding the ones for which data are not completely available over the coverage period. The dependent variable is the stock of cash and cash equivalents as a percentage of market capitalization, which is regressed on variables which we expect to impact corporate cash holdings. The effect of corporate governance in the regression is captured by the "Proprietary Bloomberg Score" an index which ranges from 0.1 for companies that disclose a minimum amount of governance data to 100 for those that disclose every data point collected by Bloomberg. Each data point is weighted in terms of importance, with board of directors data carrying a greater weight than other disclosures. The score is also tailored to different industry sectors. In this way, each company is only evaluated relative to its industry sector. The choice of this variable as a proxy for corporate governance was mostly driven by data availability at the firm level (see the Appendix for more details on variables' definitions and data sources).

Regressors also include controls for other factors which we expect to affect cash holdings. According to the trade-off theory (Opler et al. 1999; Dittmar et al. 2003) firms hold more cash when they are smaller, have higher investment opportunities, and have higher cash flow concerns, because these are characteristics which either increase the cost of cash shortfalls or increase the cost of raising funds. As proxies for firms' size and investment, the regression includes the number of employees and the value of common stock - which are expected to have negative signs - and capital expenditures, which is expected to have a positive sign. ${ }^{3}$ As a proxy for cash flow concerns, the regression includes the cash conversion cycle, defined as Inventory Turnover Days + Account Receivable Turnover Days - Accounts Payable Turnover Days. This variable is expected to have a positive sign, since the trade-off theory postulates that firms which take longer to convert their resources into cash want to keep a higher stock of cash. The regression also includes the free cash flow per share which is expected to have a positive sign, in accordance with predictions of the financing-hierarchy theory that firms with high cash flows will hold more cash. In order to capture the effect of bank power on cash holdings stressed by Pinkowitz and Williamson (2001), the debt-to-equity ratio is also included. This variable is interpreted as a broad measure of banks' monopolistic power in lending and it is expected to have a positive sign. Lags of the dependent variable are also included to control for autocorrelation and habit formation in cash holding.

These three variables enter the regression in logarithmic form. 
The results suggest that better corporate governance reduces cash holdings. Table 2 summarizes the panel regression for various estimation techniques. Regardless of the specific estimation method used, the indicator of corporate governance always has a negative sign, suggesting that improving corporate governance would reduce corporate cash holdings in Japan. The coefficient is also significant at the 10 percent level for fixed effects estimation with default standard errors and at the 1 percent level using random effects and Arellano Bond estimations. If fixed effects with robust standard errors are used, the coefficient is still negative but the level of significance is reduced to 15 percent. A Hausman test rejected the null hypothesis that a random effect model would be statistically different from a fixed effects one, suggesting that a fixed effect model is preferred.

Table 2.

Determinants of Cash Holdings in a Panel of Japanese Firms: Regression Results ${ }^{1)}$

\begin{tabular}{|c|c|c|c|c|}
\hline & Fixed Effects & $\begin{array}{l}\text { Fixed Effects } \\
\text { (Robust SE) }\end{array}$ & Random Effects & $\begin{array}{l}\text { Arellano Bond } \\
\text { (Robust SE) }\end{array}$ \\
\hline \multicolumn{5}{|c|}{ Dependent Variable: Cash Holdings in Percent of Market Capitalization } \\
\hline Governance Index & $\begin{array}{l}-0.089 \\
{[-1.82]^{*}}\end{array}$ & $\begin{array}{l}-0.089 \\
{[-1.44]^{2)}}\end{array}$ & $\begin{array}{l}-0.380 \\
{[-8.59]^{* * *}}\end{array}$ & $\begin{array}{l}-0.565 \\
{[-4.73]^{* * *}}\end{array}$ \\
\hline Log of Common Stock & $\begin{array}{l}-0.380 \\
{[-0.69]}\end{array}$ & $\begin{array}{l}-0.380 \\
{[-0.78]}\end{array}$ & $\begin{array}{l}0.280 \\
{[1.35]}\end{array}$ & $\begin{array}{l}0.092 \\
{[0.16]}\end{array}$ \\
\hline Log of Number of Employees & $\begin{array}{l}8.179 \\
{[4.45]^{* * *}}\end{array}$ & $\begin{array}{l}8.179 \\
{[2.81]^{* * *}}\end{array}$ & $\begin{array}{l}2.002 \\
{[5.17]^{* * *}}\end{array}$ & $\begin{array}{l}10.513 \\
{[2.13]^{* *}}\end{array}$ \\
\hline Cash Conversion Cycle & $\begin{array}{l}-0.009 \\
{[-0.72]}\end{array}$ & $\begin{array}{l}-0.009 \\
{[-0.37]}\end{array}$ & $\begin{array}{l}-0.003 \\
{[-0.82]}\end{array}$ & $\begin{array}{l}-0.013 \\
{[-0.67]}\end{array}$ \\
\hline Log of Capital Expenditure & $\begin{array}{l}-1.838 \\
{[-3.42]^{* * *}}\end{array}$ & $\begin{array}{l}-1.838 \\
{[-2.30]^{* *}}\end{array}$ & $\begin{array}{l}-2.187 \\
{[-7.78]^{* * *}}\end{array}$ & $\begin{array}{l}-0.268 \\
{[-0.31]}\end{array}$ \\
\hline Debt-to-Equity Ratio & $\begin{array}{l}0.010 \\
{[3.70]^{* * *}}\end{array}$ & $\begin{array}{l}0.010 \\
{[1.61]}\end{array}$ & $\begin{array}{l}0.005 \\
{[2.61]^{* * *}}\end{array}$ & $\begin{array}{l}0.010 \\
{[1.83]}\end{array}$ \\
\hline Free Cash Flow per Share & $\begin{array}{l}0.007 \\
{[2.77]^{* * *}}\end{array}$ & $\begin{array}{l}0.007 \\
{[2.20]^{* *}}\end{array}$ & $\begin{array}{l}0.002 \\
{[1.18]}\end{array}$ & $\begin{array}{l}0.015 \\
{[3.90]^{* * *}}\end{array}$ \\
\hline Lagged Dependent Variable $(\mathrm{t}-1)$ & $\begin{array}{l}0.095 \\
{[7.26]^{* * *}}\end{array}$ & $\begin{array}{l}0.095 \\
{[1.93]^{* *}}\end{array}$ & $\begin{array}{l}0.786 \\
{[98.32]^{* * *}}\end{array}$ & $\begin{array}{l}0.166 \\
{[3.68]^{* * *}}\end{array}$ \\
\hline R-squared (overall) & 0.060 & 0.060 & 0.647 & $\ldots$ \\
\hline
\end{tabular}

\footnotetext{
${ }^{*}$ denotes significance at $10 \%$ level, ${ }^{* *}$ significance at $5 \%$ level, and ${ }^{* * *}$ significance at $1 \%$ level.

1) T-statistics are reported in parenthesis.

2) Level of significance is 15 percent.

Source: IMF Staff Calculations.
}

Several other factors also have an impact on cash holdings. In accordance with the prediction of the trade-off theory, firms' size as captured by the log of common stock has a negative coefficient when fixed effects are used. However, the coefficient turns positive for other estimation techniques and is in general not significant. The number of employees has a positive and highly significant coefficient, which is in contrast with the prediction of the trade-off theory, but could be explained in the Japanese context by the "aversion to bankruptcy" channel highlighted by Kinoshita (2013), and discussed in Section III, i.e. firms which are more labor-intensive might accumulate more cash as a way to avoid bankruptcies and protect employment. The cash conversion cycle has a negative sign in contrast with the predictions of the trade-off theory but it is not significant. The cash flow per share has the expected positive sign according to the financing-hierarchy theory and 
is statistically significant. This result is also consistent with the finding by Horioka and TeradaHagiwara (2013) on a panel of firms from 11 Asian countries. The debt-to-equity ratio has a positive and mostly significant coefficient, confirming the result by Pinkowitz and Williamson (2001) that higher banks' monopolistic power tends to push companies to hoard cash in Japan. The impact of capital expenditure is negative and mostly significant, which is contrary to the trade-off theory, but can be explained in terms of the financing-hierarchy theory.

The estimated impact of improving corporate governance on cash holdings in Japan is sizeable. In line with findings from other cross-country governance indicators mentioned above, the corporate governance proxy used in the regressions also indicates that Japanese firms' governance score on average was lower than that of other advanced countries, except Germany, for most years between 2000 and 2013 (or less depending on data availability). Table 3 shows estimates of how much improving corporate governance - as measured by the index we use in the regression - could contribute to reducing cash holdings on the basis of our results. Specifically, the table shows by how much cash holdings could be reduced for a representative Japanese firm if the index were to improve from the Japanese firms' panel average of 41.5 to the maximum in Japanese firms' panel of 62.5; and the theoretical maximum value that the index could take of 100 . The results vary depending on which regression coefficients are used amongst the ones presented in Table 2, which correspond to various estimation methods. Overall, Table 3 suggests that the effect of improving corporate governance on cash holdings could be sizeable, since the estimated reductions in the cash-to-market capitalization ratio range from about 2 to about 33 percentage points.

Table 3.

Estimated Reduction in Cash Holdings Due to Improvement in Corporate Governance (cash to market capitalization, percentage points)

\begin{tabular}{|c|c|c|c|c|}
\hline & Fixed Effects & Random Effects & Arellano-Bond & $\begin{array}{c}\text { Average } \\
\text { of Estimation } \\
\text { Methods }\end{array}$ \\
\hline $\begin{array}{l}\text { Average to Maximum in Panel } \\
\text { (index from } 41.5 \text { to } 62.5 \text { ) }\end{array}$ & 1.9 & 8.0 & 6.9 & 5.6 \\
\hline $\begin{array}{l}\text { Average to Theoretical Maximum } \\
\text { (index from } 41.5 \text { to } 100 \text { ) }\end{array}$ & 5.2 & 22.2 & 33.1 & 20.2 \\
\hline
\end{tabular}

Source: IMF staff calculations.

In interpreting these results some caveats need to be kept in mind. First of all, the results only refer to first round effects of improving corporate governance on cash holdings. If firms use the reduction in cash to finance increases in wages and investment, this will stimulate the economy and help Japan exit from deflation. A higher inflation environment, in turn, will make hoarding cash less attractive, giving further incentives to firms to reduce cash holding beyond the amount captured in the regressions. It is also important to keep in mind that the index used in the regression refers solely to disclosure of data related to corporate governance. As such, it is not necessarily a perfect proxy of corporate governance, because the fact that data are disclosed does not guarantee in itself that corporate governance practices are improved. It should therefore not be concluded that the only policy recommendation flowing from this analysis is to just improve disclosure. Rather, this empirical analysis can be seen as supporting the more general point that corporate governance and legal-framework reforms can contribute to reducing corporate cash holdings. With this in mind, the next section will discuss the progress made so far in improving corporate governance in Japan, and discuss some options for further reform. 


\section{OPTIONS FOR CORPORATE GOVERNANCE REFORM IN JAPAN}

The discussion and empirical analysis presented in the previous section suggest that corporate governance reform should be part of Japan's growth strategy. Such reforms would help remove some of the bottlenecks of the legal and corporate governance framework which encourage high corporate cash holdings and prevent a more pro-growth use of resources. Corporate governance reforms would also enhance the transmission of the BoJ's Quantitative and Qualitative Easing (QQE) framework, by reducing cash holdings, contributing to investment and wage growth and therefore stimulating actual and expected inflation.

The government has made a step forward for needed corporate governance reform. In June 2014, the Companies Act was amended to encourage the appointment of outside directors. The amended Companies Act requires listed companies who do not appoint outside directors to provide an explanation at their annual shareholders' meeting. Underpinning the "comply or explain" rule is the principle that outside directors should be appointed at listed companies unless there are good reasons for not doing so.

Japan also introduced in February 2014 a Stewardship Code aimed at increasing fiduciary responsibilities of institutional investors. Such a code will encourage investors to push managers to maximize shareholders' value rather than pursuing individual benefits. The JPX-Nikkei 400 Index which was launched in January 2014 is also expected to improve corporate governance. The JPX-Nikkei 400 Index is Japan's first broad stock index that includes only profitable companies with good corporate governance. The index is expected to have a positive impact on corporate behavior by exerting pressure to improve profitability and corporate governance. ${ }^{4}$

Indeed, recent developments suggest that the introduction of the Stewardship Code and the JPX-Nikkei 400 Index might result in Japanese institutional investors taking a more active role in improving firms' corporate governance. Japan's nearly 130-trillion yen ( $\$ 1.3$ trillion) public pension fund (GPIF) accepted the Stewardship Code, a move expected to improve equity returns through more engagement with companies whose stock it owns. Adoption of the code by GPIF is expected to encourage other institutional investors to follow suit, and in fact as of February 2015, 184 institutional investors, including most of the largest Japanese asset managers, had subscribed to the code. JPX-Nikkei 400 is becoming increasingly popular benchmark amongst individual and institutional investors, and the assets under management of funds linked to the index reached more than 2 trillion yen as of end-January 2015 .

In addition, the Tokyo Stock Exchange (TSE) adopted a corporate governance code on June 1, 2015. The corporate code aims at complementing the Stewardship Code. The code contains requirements for companies to i) appoint at least two outside directors on a "comply or explain" basis; and ii) to explain their rationale for cross-shareholding and anti-takeover measures.

Despite these positive developments, since the empirical analysis presented in this paper suggests that the gains from improving corporate governance could be large, reforms aimed at discouraging excessive corporate savings could be more ambitious. In particular, the following additional measures could be considered:

- Expanding the use of outside directors and reinforcing their independence. The percentage of listed companies which have appointed outside directors increased from 47 percent in 2013 to 61 percent in 2014: however the percentage of outside directors out of total directors remain low at 8 percent, reflecting the fact that most companies only have one or two outside directors. This ratio is extremely low compared to other advanced countries. For example, the proportion of independent outside directors is about 70 percent in the United States, 50 percent or higher in the United Kingdom, and greater than 30 percent in South Korea (Miyajima 2012). Most other advanced countries require a substantial number of outside directors either in a mandatory way

\footnotetext{
4 Central to the calculation of the JPX-Nikkei 400 is a three-year-record of return on equity employed (ROE), along with various qualitative measures of corporate governance, such as independent directors and reports in English.
} 
(more than half of the board in the US, more than one quarter of the board in Korea) or under a "comply or explain" approach (e.g. more than half of the board in the UK, an "appropriate number" in Germany, and half of the board in France). Considering the experience of other countries, there seems therefore to be scope for expanding the use of outside directors even more, either by adopting a US-style mandatory approach, or by increasing the number of independent outside directors required under the "comply or explain" approach, as done for example in the UK and France. While having multiple independent directors in the board may not be sufficient, by itself, to reduce cash holdings, it seems an important determinant, suggesting that it should be a necessary and important component of comprehensive corporate governance reform. As shown in the text chart, although the level of cash holdings varies among companies with zero or a very low share of independent directors, it is rare for companies with high shares of independent directors to have extremely high cash holdings. At the same time, very high cash holdings tend to be associated with relatively low shares of independent directors. All 67 cases of Japanese non-financial listed companies with greater than 100 percent cash-to-market capitalization ratio in 2013 occurred in companies whose share of independent directors in total board membership is less than 30 percent.

Cash Holdings and Independent Directors (Non financial Listed Companies in Japan; 2013)

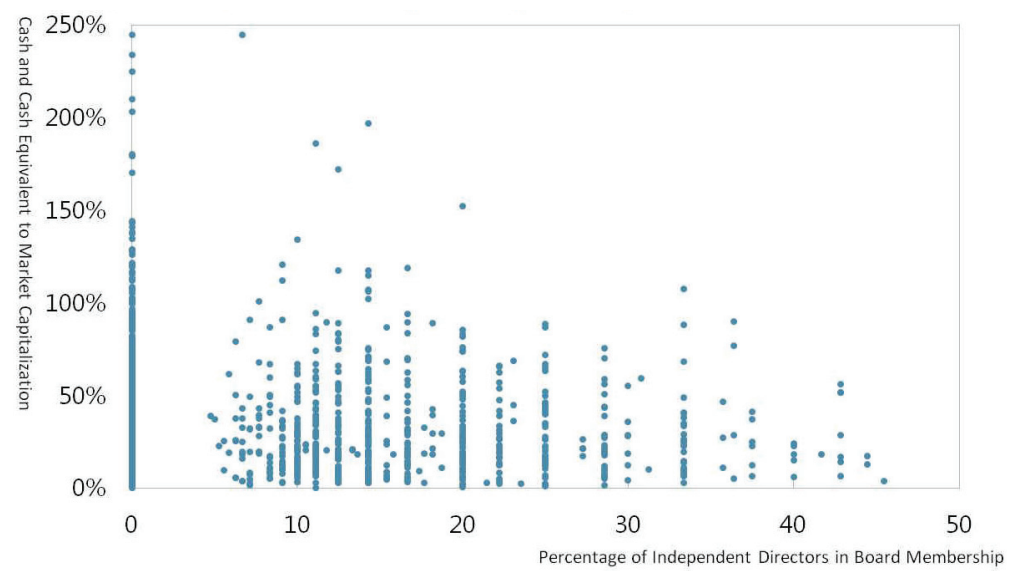

Sources: Bloomberg.

- Measures to enhance board diversity. Diversification of the board members can balance decision making by bringing different points of view. According to a study of Fortune 500 companies (Catalyst 2007), companies with more female board directors outperform those with the least, for several financial measures such as Return on Equity, Return on Sales and Return on Invested Capital. In Japan, there is scope to improve the representation of women and foreigners in boards. For example, while women account for $20.7 \%$ of board members in the U.K and $16.9 \%$ in the U.S., the figure in Japan is only a $1.1 \% .5$ Having more women in boards would also create role models for working women and generate synergies with reforms aimed at increasing female labor participation, which are important for growth (see Steinberg and Nakane 2012). Having more foreigners in corporate boards could also help Japanese corporations in expanding abroad and exploring new markets, which would help counteract the effects of Japan's declining and aging population.

- Implementation of tax and regulatory reforms which would reduce incentives for shareholders to pursue "individual" rather than monetary benefits. In this context, limits or measures which create incentives to end excessive cross-shareholdings could be considered. For example, tax reforms were successful in Germany in the early 2000s in reducing cross-shareholding, although 
it increased again from 2007. Also, cross shareholdings in OECD countries are frequently limited by law (OECD 2007). Similar tax and legal reforms could be considered in Japan.

- Measures aimed at reducing the threat faced by firm managers in case of filing for bankruptcy, for example by introducing pre-packaged reorganization plans such as those available in the US under Chapter 11. Such measures would reduce the incentives for corporations to hold cash as insurance against filing for bankruptcy. Also it is important that the government follows up on its plans to propose legislation which would limit business owners' individual liability in case of bankruptcy, since such a measure would reduce the threat associated with filing for bankruptcy. Plans to encourage creditor-led debt workout to make it easier for companies to have debt forgiven, a move aimed at encouraging quicker corporate rehabilitation, would also help if implemented.

- Removing bottlenecks which prevent takeovers, such as reducing the asymmetry between the duties of the bidder and those of the target enterprise in takeover regulations and introducing a more favorable tax treatment for the owners of stocks of companies which are acquired. These measures would encourage takeovers, therefore putting pressures on managers to prioritize profitability over cash holdings as cash-rich companies are likely to be considered takeover targets.

\section{CONCLUSIONS}

This paper argues that Japan's excessive corporate savings might be holding back growth, by preventing a more efficient use of resources. The literature has identified various determinants of cash holdings, including good corporate governance, which usually contributes to reducing excessive corporate savings by putting pressure on managers to act in shareholders' interests. This paper argues that this channel is likely to be particularly important in Japan, given its low scores, compared to other G-7 countries, in terms of corporate governance indexes.

The hypothesis of a relationship between improving corporate governance and unlocking corporate savings in Japan is confirmed by the empirical analysis carried out in the paper. Panel regressions on a panel of about 3,400 Japanese firms suggest that improving corporate governance in Japan - proxied by an index summarizing company disclosure of governance data - could significantly reduce corporate cash holdings.

On the basis of this empirical analysis, it can be concluded that comprehensive corporate governance reform should be a key component of Japan's growth strategy. The steps recently taken by the authorities in this area - such as the introduction of the Stewardship Code for institutional investors and plans to encourage the use of outside directors on a "comply or explain" basis - go in the right direction. However, reforms could be more ambitious. In this regard, possible additional measures could include expanding the use of outside directors beyond current plans. With such additional measures, we expect that firms' resources will be used in a more efficient way, such as additional investment and increase in wages, and that this will lead to improvements in both potential and short term growth for the whole economy. We also hope that the reported finding in this study can be useful for policy-makers to consider corporate governance reforms aimed at unlocking corporate savings.

\section{Acknowledgements}

We are grateful to Nobuyuki Kinoshita for very useful discussion. We also thank an anonymous referee, Dennis Botman, Stephan Danninger, Jerry Schiff, and participants in the IMF seminar held in Tokyo on "Towards a more dynamic business sector" for their comments. 


\section{References}

Aggarwal, Reena, Isil Erel, Miguel Ferreira and Pedro Matos, 2010, "Does Governance Travel Around the World? Evidence from Institutional Investors," Fisher College of Business Working Paper No. 2009-008 (Ohio: the Ohio State University).

Catalyst, 2007, “The Bottom Line: Corporate performance and women's representation on boards".

De Nicolò, Gianni, Luc Laeven, and Kenichi Ueda, 2006, "Corporate Governance Quality: Trends and Real Effects," IMF Working Paper06/293 (Washington: International Monetary Fund).

Dittmar, Amy, Jan Mahrt-Smith, and Henri Servaes, 2003, “International Corporate Governance and Corporate Cash Holdings", Journal of Financial and Quantitative Analysis Vol. 38, No. 1, March 2003.

Fazzari, Steven M., Hubbard, R. Glenn, and Bruce C. Petersen, 1988, "Financing Constraints and Corporate Investment", Brookings Papers on Economic Activity Vol. 19, pp. 141-195.

Horioka, Charles Yuji, and Akiko Terada-Hagiwara, 2013, "Corporate Cash Holdings in Asia”, NBER Working Paper 19688.

Ivanova, Anna, and Faezeh Raei, 2014, “Corporate Cash Holdings: Are German Companies Different?”. Forthcoming, IMF Working Paper.

Jensen, Michael C. and William H. Meckling, 1976, “Theory of the Firm: Managerial Behavior, Agency Costs and Ownership Structure", Journal of Financial Economics 3, pp. 305-360.

Keynes, John Maynard, 1934, “The General Theory of Unemployment”. In: Interest and Money. Harcourt Brace, London.

Kinoshita, Nobuyuki, 2013, "Legal Background to the Low Profitability of Japanese Enterprises," Center on Japanese Economy and Business Working Papers No.316 (New York: Columbia University).

Kinoshita, Nobuyuki, 2014, "Comparison of Enterprise Law in Japan, Germany and the United States", slides presentation.

Kusnadi, Y., Wei, K.C.J., 2011, “The determinants of corporate cash management policies: Evidence from around the world", Journal of Corporate Finance, 17 (3), pp. 725-740.

La Porta, Rafael, Lopez-de-Silanes, Florencio, Shleifer, Andrei, and Robert. W. Vishny, “Agency Problems and Dividend Policies Around the World," Journal of Finance Vol. 55, pp. 1-33.

Meltzer, A. H., 1993, “The Demand for Money: A Cross-Section Study of Business Firms," Quarterly Journal of Economics, 77 (1993), Vol. 77, pp. 405-422.

Miller. M.H. and D. Orr, 1966, “A Model of the Demand for Money by Firms," Quarterly Journal of Economics Vol. 80, pp. 414-435.

Miyajima, Hideaki , 2012, "Pros and Cons of Mandating the Appointment of Outside Directors: Based on new empirical testing" available online at http://www.rieti.go.jp/en/papers/contribution/miyajima/03.html

Mulligan, C. B., 1997, "Scale Economies, the Value of Time, and the Demand for Money: Longitudinal Evidence from Firms" Journal of Political Economy Vol. 105, pp. 1061-1079.

Myers, Stewart. C., and Nicolas Majluf, 1984, "Corporate Financing and Investment Decisions When Firms Have Information That Investors Do Not Have,” Journal of Financial Economics Vol. 13, pp. 187-221.

Nakajima, Kan, 2013, “Ko-pore-to gabanansu to kigyou no genkin hoyu” (Corporate Governance and Companies' Cash Holdings), Securities Analysts Journal 2013.6 (Tokyo: The Securities Analysts Association of Japan). Nakano, Makoto and Takasu, Yusuke, 2013, "Nihon kigyo no genkin hoyu kettei youin bunseki- shoyu kouzou to torishimariyakukai tokusei no shiten kara" (Determinants of Japanese Companies' Cash Holdings - From the point of view of the board of directors and ownership structure characteristics). HERMES-IR No.161 (Tokyo: Hitotsubashi University).

OECD, 2007, "Lack of Proportionality Between Ownership and Control: Overview and Issues for Discussion". Issued by the OECD Steering Group on Corporate Governance.

Opler, Tim, Pinkowitz, Lee, Stulz, Rene, and Rohan Williamson, 1999, “The Determinants and Implications of Corporate Cash Holdings," Journal of Financial Economics, Vol. 52, pp. 3-46.

Lee Pinkowitz and Rohan Williamson, 2001, "Bank Power and Cash Holdings: Evidence from Japan”, Review of Financial Studies, Vol. 14, Issue 4, pp. 1059-1082.

Shinada, Naoki, 2012, "Firms' Cash Holdings and Performance: Evidence from Japanese Corporate Finance," RIETI Discussion Paper Series 12-E-031.

Steinberg, Chad, and Masato Nakane, 2012, “Can Women Save Japan?” IMF Working Paper 12/248 (Washington: International Monetary Fund).

Yung, K., Nafar, N.A., 2014, "Creditor rights and corporate cash holdings: International evidence", International Review of Economics and Finance, 33, pp. 111-127. 


\section{APPENDIX}

\section{A. Benchmark Model}

An econometric model of determinants of corporate cash holdings was estimated for a panel of 3,412 non-financial Japanese firms for the 14 years between 2000 and 2013 (or less, depending on availability). Regressions were conducted using both fixed and random effects, as well as Arellano-Bond estimation with one lag.

The dependent variable is cash and cash equivalent in percent of market capitalization, available from Bloomberg.

Explanatory variables and data sources are as follows:

- The proxy for corporate governance is the "Proprietary Bloomberg Score", an index which ranges from 0.1 for companies that disclose a minimum amount of governance data to 100 for those that disclose every data point collected by Bloomberg. Each data point is weighted in terms of importance, with board-of-directors data carrying greater weight than other disclosures. The score is also tailored to different industry sectors. In this way, each company is only evaluated in terms of the data that is relevant to its industry sector.

- Common stock (which enters the regression in logarithmic form), value of common stock as reported by the company, from Bloomberg.

- Number of employees of the firm (which enters the regression in logarithmic form), from Bloomberg.

- Cash conversion cycle defined as Inventory Turnover Days + Account Receivable Turnover Days - Accounts Payable Turnover Days, from Bloomberg.

- Capital expenditure (which enters the regression in logarithmic form), from Bloomberg.

- Debt-to-equity ratio, defined as the sum of short term and long term borrowings divided by total shareholder's equity, multiplied by 100 from Bloomberg.

- Free cash flow per share, calculated as free cash flow (cash from operations - capital expenditures) divided by the average basic number of shares for the period, from Bloomberg. 